Finanse, Rynki Finansowe, Ubezpieczenia nr 3/2017 (87), cz. 1

\title{
Rola komitetu audytu w ocenie funkcjonowania kontroli zarządczej $\mathrm{w}$ ministerstwie
}

\author{
Dariusz Kotarski
}

\begin{abstract}
Streszczenie: $\mathrm{Cel}$-Określenie roli i zadań komitetu audytu w ocenie funkcjonowania kontroli zarządczej na przykładzie wybranych ministerstw, ze szczególnym uwzględnieniem uregulowań organizacyjnych, prawnych i wykonawczych.

Metoda badania - Wykorzystano metodę analizy dokumentacji w zakresie oświadczeń o stanie kontroli zarządczej ministrów oraz sprawozdań z realizacji zadań komitetów audytu w latach 2012-2016.

Wynik-Analizowano aktualne rozwiązania, dotyczące podejmowanych działań w komitetach audytu w celu zapewnienia funkcjonowania efektywnej kontroli zarządczej oraz audytu wewnętrznego. Przedstawiono również zakres świadczenia doradztwa na rzecz ministra kierującego działem oraz sposoby oceny oświadczenia o stanie kontroli zarządczej.

Oryginalność/wartość - Ocena rozwiązań i działań komitetu audytu w zakresie zapewnienia funkcjonowania adekwatnej, skutecznej i efektywnej kontroli zarządczej w wybranych ministerstwach.
\end{abstract}

Słowa kluczowe: komitet audytu, kontrola zarządcza, audyt wewnętrzny, ministerstwo

\section{Wprowadzenie}

Zasadniczym celem audytu wewnętrznego w administracji rządowej jest wspieranie ministra kierującego działem w realizacji celów i zadań. Wprowadzona od 1 stycznia 2010 roku ustawa o finansach publicznych zobowiązała wszystkich ministrów kierujących swoimi działami do powołania - w drodze zarządzenia - komitetów audytu, których zadaniem jest świadczenie doradztwa w zakresie zapewnienia funkcjonowania adekwatnej, skutecznej i efektywnej kontroli zarządczej oraz monitorowanie efektywności pracy audytu wewnętrznego.

Głównym celem artykułu jest określenie roli komitetu audytu w ocenie funkcjonowania systemu kontroli zarządczej w wybranych ministerstwach i ich działach administracji rządowej, ze szczególnym uwzględnieniem uregulowań organizacyjnych, prawnych i wykonawczych. Wykorzystano metodę analizy dokumentacji oświadczeń o stanie kontroli zarządczej ministrów oraz sprawozdań z realizacji zadań komitetów audytu w latach 2012-2016.

\footnotetext{
* dr Dariusz Kotarski, Politechnika Koszalińska, Wydział Nauk Ekonomicznych, Zakład Rachunkowości, e-mail: dariusz.kotarski@tu.koszalin.pl.
} 


\section{Organizacja komitetu audytu}

Na potrzeby prowadzenia kontroli w sektorze finansów publicznych audyt wewnętrzny może być rozpatrywany nie tylko w ujęciu funkcjonalnym, jako zespołu czynności doradczych i oceniających, ale również - w znaczeniu strukturalnym, jako pewien system podmiotów audytorów wewnętrznych i instytucji, podległy nadzorowi ministra finansów, który pełni rolę głównego koordynatora systemu kontroli finansowej i audytu wewnętrznego w Polsce (Chojna-Duch, 2010, s. 53). W strukturze organizacyjnej poszczególnych ministerstw mogą funkcjonować równolegle komórki audytu wewnętrznego oraz komitet audytu. Komórka audytu wewnętrznego pełni funkcję służebną wobec działań komitetu audytu przez zapewnienie jego obsługi organizacyjnej oraz dostarczania wsparcia informacyjnego. Ponadto, komórka audytu wewnętrznego w ministerstwie gromadzi plany audytu, sprawozdania z wykonania planów oraz inne, niezbędne dla komitetu audytu, informacje $\mathrm{z}$ jednostek $\mathrm{w}$ dziale oraz przygotowuje zbiorcze informacje o istotnych rodzajach ryzyka i słabościach kontroli zarządczej oraz proponowanych usprawnieniach kontroli zarządczej.

Zgodnie z zapisami ustawy o finansach publicznych z 2009 roku zakres działalności komitetu audytu, sprowadza się do świadczenia doradztwa na rzecz ministra kierującego działem w zakresie zapewnienia funkcjonowania adekwatnej, skutecznej i efektywnej kontroli zarządczej oraz skutecznego audytu wewnętrznego. Do zadań komitetu audytu należy w szczególności (Ustawa z 27 sierpnia 2009 r., art. 288 ust. 4 i art. 289, ust. 1):

- sygnalizowanie istotnych rodzajów ryzyka,

- sygnalizowanie istotnych słabości kontroli zarządczej oraz proponowanie jej usprawnień,

- wyznaczanie priorytetów do rocznych i strategicznych planów audytu wewnętrznego,

- przegląd istotnych wyników audytu wewnętrznego oraz monitorowanie ich wdrożenia,

- przegląd sprawozdań z wykonania planu audytu wewnętrznego oraz z oceny kontroli zarządczej,

- monitorowanie efektywności pracy audytu wewnętrznego, w tym przeglądanie wyników wewnętrznych i zewnętrznych ocen pracy audytu wewnętrznego,

- wyrażenie zgody na rozwiązanie stosunku pracy oraz zmianę warunków płacy i pracy kierowników komórek audytu wewnętrznego.

Katalog obowiązków komitetu audytu zawarty w art. 289 ust. 1 ustawy o finansach publicznych nie ma charakteru zamkniętego. Uzupełnieniem ustawowych zadań komitetu audytu może być zbiór „dobrych praktyk” - zarekomendowanych przez Ministerstwo Finansów - w celu zapewnienia funkcjonowania adekwatnej, skutecznej i efektywnej kontroli zarządczej oraz audytu wewnętrznego w ministerstwie. Propozycję dodatkowych (szczegółowych) działań i zadań komitetu audytu w zakresie zapewnienia kontroli zarządczej i audytu wewnętrznego przedstawiono w tabeli 1 . 


\section{Tabela 1}

Wybrane działania i zadania komitetu audytu w zakresie zapewnienia kontroli zarządczej oraz audytu wewnętrznego w ministerstwie

\section{Kontrola zarządcza w ministerstwie}

1. Wyznaczanie priorytetów do rocznych planów audytu po uprzednim dokonaniu analizy celów określonych w projekcie planu działalności danego ministra.

2. Monitorowanie wykonania planu działalności ministra.

3. Przegląd procedur i propozycji dotyczących zarządzania ryzykiem w organizacji.

4. Monitorowanie działań podejmowanych w ministerstwie w celu obniżenia lub eliminacji zidentyfikowanych wcześniej rodzajów ryzyka.

5. Świadczenie czynności doradczych w zakresie wydania przez ministra oświadczenia o stanie kontroli zarządczej.

6. Monitorowania stanu wdrożenia programu naprawczego opracowanego przez ministra w związku z wypełnieniem Części B lub C oświadczenia o stanie kontroli zarządczej za ubiegły rok.

7. Podjęcia działań zmierzających do identyfikacji jednostek (np. przez monitorowanie wysokości dochodów i wydatków), które są zobowiązane do prowadzenia audytu wewnętrznego*.

8. Monitorowanie zgodności działalności wybranych jednostek w dziale z obowiązującymi przepisami prawa i regulacjami wewnętrznymi
Audyt wewnętrzny w ministerstwie

1. Przekazywanie audytorom wewnętrznym zaleceń co do spodziewanych efektów ich pracy.

2. Prezentowanie wyników audytów wewnętrznych, które odnosiły się do strategicznych obszarów działania ministerstwa, podczas posiedzeń kierownictwa ministerstwa.

3. Monitorowanie niezależność audytu wewnętrznego przy jednoczesnej ocenie jego obiektywizmu oraz efektywności.

6. Monitorowanie alokacji zasobów audytu wewnętrznego określonych w rocznym planie audytu w celu uzyskania gwarancji, że planowane audyty wewnętrzne są odpowiednio dostosowane do głównych zagrożeń związanych.

$\mathrm{z}$ funkcjonowaniem jednostek w dziale

7. Monitorowanie stopnia wdrożenia zaleceń audytu wewnętrznego.

8. Ocena audytorów wewnętrznych pod względem stosowania standardów pracy i podnoszenia kwalifikacji poprzez uczestnictwo w szkoleniach

\footnotetext{
" Działanie takie ma na celu przyporządkowanie jednostek do odpowiedniego działu administracji rządowej, a zarazem uniknięcie niekompletności wykazu jednostek podległych lub nadzorowanych publikowanych w obwieszczeniach poszczególnych ministrów.
}

Źródło: opracowanie własne na podstawie Dobre praktyki... (2013), s. 10-11.

W skład komitetu audytu wchodzi nie mniej niż trzech członków, w tym jedna wskazana przez ministra osoba w randze sekretarza lub podsekretarza stanu jako przewodniczący komitetu oraz co najmniej dwie osoby, niebędące pracownikami ministerstwa lub jednostek w dziale, tzw. członkowie niezależni (Ustawa z 27 sierpnia 2009 r., art. 290, ust. 1).

Ustawowy obowiązek wskazania przez ministra przewodniczącego komitetu audytu w randze sekretarza lub podsekretarza istotnie warunkuje zależność służbową i ogranicza możliwość wyboru osoby na to stanowisko. Niezależnie od sposobu wyboru osoby, każdy przewodniczący komitetu audytu powinien legitymować się wiedzą i doświadczeniem w zarządzaniu zespołem oraz mieć odpowiednie cechy osobowości niezbędne do pełnienia wyznaczonej roli, jaką jest kierowanie pracami komitetu i zapewnienie aktywnego i skutecznego uczestnictwa wszystkich członków w pracach komitetu audytu. Do zadań przewodniczącego należy również: 1) ustalanie porządku obrad; 2) monitorowanie 
prawidłowości funkcjonowania komitetu; 3) zapewnianie właściwego i terminowego dostarczenia członkom komitetu adekwatnych i kompleksowych informacji oraz zapewnienie wystarczającego czasu na podjęcie stosownych decyzji; 4) dbanie o rozwój członków komitetu, dając możliwość uzupełnienia wiedzy w niezbędnych im dziedzinach prac audytorskich (Dobre praktyki..., 2013, s. 12).

Organizację i tryb pracy komitetu audytu określa regulamin komitetu audytu utworzony przez ministra, na wniosek przewodniczącego komitetu. Regulamin powinien określać w szczególności (Rozporządzenie Ministra Finansów z dnia 20 maja 2016 r., par. 1):

a) szczegółowy zakres zadań komitetu audytu;

b) sposób działania komitetu audytu, w tym:

- tryb i częstotliwość zwoływania posiedzeń,

- sposób prowadzenia posiedzeń,

- sposób podejmowania uchwał,

- zasady udziału w posiedzeniach osób trzecich,

- sposób dokumentowania posiedzeń oraz podjętych ustaleń;

c) sposób i tryb dostępu członków komitetu audytu do dokumentów, informacji i innych materiałów związanych z funkcjonowaniem kontroli zarządczej i audytu wewnętrznego w jednostkach w dziale, przy zachowaniu przepisów o tajemnicy ustawowo chronionej;

d) sposób i tryb współpracy członków komitetu audytu z kierownikami oraz pracownikami jednostek w dziale lub działach, dla których został powołany komitet audytu;

e) sposób i tryb współpracy komitetu audytu z kierownikami komórek audytu wewnętrznego;

f) tryb postępowania w sprawach o wyrażenie zgody na rozwiązanie stosunku pracy albo zmianę warunków pracy i płacy kierownika komórki audytu wewnętrznego, z uwzględnieniem zapewnienia pracodawcy oraz kierownikowi komórki audytu wewnętrznego możliwości udziału w postępowaniu.

W praktyce członkowie komitetu audytu współpracują z kierownikami i pracownikami jednostek poszczególnych ministerstw oraz z kierownikami komórek audytu wewnętrznego w zakresie realizacji wyżej wymienionych zadań regulaminowych. Wiąże się to m.in. z prawem wglądu do dokumentów, informacji i innych materiałów dotyczących funkcjonowania kontroli zarządczej oraz audytu wewnętrznego w jednostkach organizacyjnych ministerstwa, w szczególności do: 1) akt stałych i akt bieżących komórek audytu wewnętrznego, z zachowaniem przepisów o tajemnicy ustawowo chronionej, np. planów audytów, sprawozdań z wykonania planów audytów, sprawozdań z zadań audytowych, dokumentów wytworzonych lub otrzymanych przez audytora wewnętrznego w związku z wykonywaniem czynności doradczych (Rozporządzenie Ministra Finansów z dnia 1 lutego 2010 r., par. 14 i 15); 2) wyników okresowych ocen prowadzenia audytu wewnętrznego; 3) innych materiałów pisemnych, które zawierają kluczowe wskaźniki ekonomiczne i finansowe oraz opisy 
czynności podjętych w celu zapobiegania zagrożeniom w ramach kontroli zarządczej (Kotarski, 2014, s. 79).

Funkcjonowanie komitetu audytu powinno zostać ocenione pod względem zgodności z przepisami prawa oraz skuteczności, z jaką spełnia on postawione przed nim cele. Komitet może w tym celu wykorzystywać wyniki samooceny dokonywanej indywidualnie przez jego członków. Podstawowym celem samooceny nie jest wzajemna ocena pracy przez poszczególnych członków komitetu, ale wykazanie, w jaki sposób działalność komitetu jako całości jest postrzegana przez osoby w nim zasiadające. Ocena pracy komitetu może zostać dodatkowo przeprowadzona przez komórkę audytu wewnętrznego obsługującą prace komitetu (Dobre praktyki..., 2013, s. 16).

\section{Ocena kontroli zarządczej w działach administracji rządowej}

Instytucje kontroli zarządczej oraz komitetu audytu wprowadziła do polskiego porządku prawnego ustawa o finansach publicznych 1 stycznia 2010 roku. Aby zapewnić adekwatną, skuteczną i efektywną kontrolę zarządczą, ministrowie w kierowanych przez siebie działach administracji rządowej ustanawiają system kontroli zarządczej (II poziom kontroli zarządczej) w stosunku do jednostek podległych i nadzorowanych (Winiarska, Postuła, 2012, s. 42-43). Zadania związane z kontrolą zarządczą ministrowie wykonują przez opracowanie zasad i procedur oraz wykorzystywanie innych mechanizmów, jakimi dysponują w stosunku do jednostek podległych.

W działach administracji rządowej, w odróżnieniu od jednostek samorządu terytorialnego oraz jednostek sektora finansów publicznych ${ }^{1}$, organizacja prac związanych w kontrolą zarządczą wiąże się z dotrzymaniem ustawowych terminów w zakresie planów, zadan, sprawozdań i ocen o stanie kontroli zarządczej. Minister kierujący działem sporządza, do końca listopada każdego roku, plan działalności na rok następny dla kierowanych przez niego działów administracji rządowej, który zawiera w szczególności określenie celów w ramach poszczególnych zadań budżetowych wraz ze wskazaniem podzadań służących osiągnięciu celów oraz mierniki określające stopień realizacji celu i ich planowane wartości. Kontynuacja prac z zakresu kontroli zarządczej następuje w następnym roku kalendarzowym, kiedy to minister kierujący działem sporządza do końca kwietnia sprawozdanie z wykonania planu działalności oraz składa oświadczenie o stanie kontroli zarządczej za poprzedni rok w kierowanych przez niego działach administracji rządowej. Plan działalności, sprawozdanie z wykonania planu działalności oraz oświadczenie o stanie kontroli zarządczej są publikowane w Biuletynie Informacji Publicznej (Ustawa z 27 sierpnia 2009 r., art. 70 , ust. 1-5).

\footnotetext{
${ }^{1}$ Minister kierujący działem może zobowiązać kierownika jednostki w dziale do sporządzania planu działalności na rok następny dla tej jednostki oraz sporządzania sprawozdania z wykonania planu działalności i składania oświadczenia o stanie kontroli zarządczej za poprzedni rok w zakresie kierowanej przez niego jednostki.
} 
Ocena kontroli zarządczej powinna wynikać z wiedzy sytuacyjnej i doświadczenia ministra kierującego działem. Konieczne jest zebranie wszystkich aktualnych informacji na temat funkcjonowania kontroli zarządczej, które umożliwią jej prawidłową ocenę. Informacje mogą pochodzić z następujących źródeł: monitoringu realizacji celów i zadań, samooceny kontroli zarządczej, systemu zarządzania ryzykiem, wyników pracy audytu wewnętrznego, wyników kontroli wewnętrznych (tj. kontroli prowadzonych przez wyspecjalizowaną komórkę kontrolną wewnątrz urzędu obsługującego ministra), wyników kontroli i audytów zewnętrznych (tj. kontroli i audytów prowadzonych przez uprawnione do tego organy kontroli i audytu lub przez uprawnionego audytora) lub innych źródeł informacji. Mogą to być również informacje pochodzące ze skarg i wniosków, wyniki audytów zewnętrznych, wnioski i rekomendacje z przeprowadzonych ocen (ewaluacji), oświadczenia o stanie kontroli zarządczej z jednostek wchodzących w skład działu administracji rządowej, opinia kierownika oraz wnioski i rekomendacje przeglądów i misji monitorujących instytucji Unii Europejskiej, innych państw lub misji organizacji międzynarodowych, do których należy Polska (Kontrola zarzadcza..., 2012, s. 102).

Zwieńczeniem organizacji prac dokumentacyjnych związanych z kontrolą zarządczą jest wydanie przez ministra kierującego działem oświadczenia o stanie kontroli zarządczej. Oświadczenie jest dokumentem, który zawiera (Ćwiklicki, 2015, s. 136-137):

a) określenie stopnia funkcjonowania kontroli zarządczej;

b) skrócony opis m.in.:

- ujawnionych nieprawidłowości w funkcjonowaniu danej jednostki,

- słabych punktów kontroli zarządczej w jednostce,

- przyczyn niepowodzeń w realizacji celów i zadań,

- dysfunkcji monitoringu kontroli zarządczej i procesu zarządzania ryzykiem w jednostce;

c) zidentyfikowane kluczowe działania, które zostaną podjęte celem poprawy funkcjonowania kontroli zarządczej w jednostce;

d) opis kluczowych działań, zarówno zaplanowanych w oświadczeniu z ubiegłego roku, jak i niezaplanowanych, a które zostały podjęte w ubiegłym roku w celu poprawy funkcjonowania kontroli zarządczej w jednostce.

W oświadczeniu o stanie kontroli zarządczej, w zależności od wyników oceny stanu kontroli zarządczej, minister wypełnia tylko jedną część z części A albo B, albo C. Część A wypełnia w przypadku, gdy kontrola zarządcza w wystarczającym stopniu zapewniła łącznie wszystkie następujące elementy:

- zgodność działalności z przepisami prawa oraz procedurami wewnętrznymi,

- skuteczność i efektywność działania,

- wiarygodność sprawozdań, ochronę zasobów,

- przestrzeganie i promowanie zasad etycznego postępowania,

- efektywność i skuteczność przepływu informacji,

- zarządzanie ryzykiem. 
Część B oświadczenia zostanie zaznaczona w przypadku, gdy kontrola zarządcza nie zapewniła $\mathrm{w}$ wystarczającym stopniu jednego lub więcej $\mathrm{z}$ wymienionych elementów. Część C wypełnia się w przypadku, gdy kontrola zarządcza nie zapewniła w wystarczającym stopniu żadnego z wymienionych elementów (Rozporządzenie z dnia 2 grudnia 2010 r.).

Odnosząc się do oceny kontroli zarządczej w wybranych ministerstwach, należy podkreślić, że w latach 2012-2016 tylko minister rolnictwa i rozwoju wsi ocenił, że kontrola zarządcza w wystarczającym stopniu realizuje cele określone w ustawie o finansach publicznych. W pozostałych działach administracji rządowej kontrola zarządcza nie była zapewniona w wystarczającym stopniu w analizowanym okresie (np. w dziale Ministerstwa Zdrowia) lub uległa pogorszeniu i wymagała usprawnień w ostatnich latach (w działach Ministerstwa Nauki i Szkolnictwa Wyższego oraz Ministerstwa Skarbu Państwa). Ocenę kontroli zarządczej w wybranych działach administracji rządowej przedstawiono w tabeli 2.

\section{Tabela 2}

Ocena kontroli zarządczej w wybranych działach administracji rządowej za lata 2012-2016

\begin{tabular}{lllllll}
\hline Lp. & Minister wydający oświadczenie & 2012 & 2013 & 2014 & 2015 & 2016 \\
\hline 1. & Minister zdrowia & B & B & B & B & B \\
2. & Minister rolnictwa i rozwoju wsi & A & A & A & A & A \\
3. & Minister skarbu państwa & A & A & B & B & b.d. \\
4. & Minister spraw wewnętrznych i administracji & B & B & B & B & B \\
5. & Minister nauki i szkolnictwa wyższego & A & A & A & B & B \\
\hline
\end{tabular}

Źródło: badanie własne na podstawie oświadczeń o stanie kontroli zarządczej ministrów w latach 2012-2016.

\section{Dzialalność doradcza komitetu audytu na potrzeby oceny kontroli zarządczej}

Działalność komitetu audytu polega m.in. na świadczeniu doradztwa na rzecz ministra kierującego działem w celu zapewnienia funkcjonowania adekwatnej, skutecznej i efektywnej kontroli zarządczej oraz audytu wewnętrznego. Komitet audytu może zarekomendować ministrowi ocenę stanu kontroli zarządczej. W badanych działach administracji komitety audytu analizowały również oświadczenia o stanie kontroli zarządczej przez:

- zapoznanie się z oświadczeniem,

- przekazanie ministrowi opinii komitetu audytu na temat stanu kontroli zarządczej,

- dokonanie przez komitet audytu oceny funkcjonowania kontroli zarządczej,

- wskazanie jej konkretnych słabości,

- monitorowanie przygotowania projektu oświadczenia o stanie kontroli zarządczej.

W przypadku zalecenia oceny o ograniczonym zakresie funkcjonowania kontroli zarządczej, komitet audytu powinien uzasadnić swoją ocenę, podając przyczyny oraz propozycje 
działań usprawniających. Należy jednak zaznaczyć, że działania te powinny wynikać tylko z pełnienia ustawowych obowiązków doradczych. Komitet audytu nie może brać na siebie odpowiedzialności za ostateczny kształt oświadczenia o stanie kontroli zarządczej. Rekomendacje lub oceny komitetu audytu w zakresie kontroli zarządczej w wybranych działach administracji rządowej za lata 2012-2016 przedstawiono w tabeli 3.

\section{Tabela 3}

Rekomendacja lub ocena komitetu audytu w zakresie kontroli zarządczej w wybranych działach administracji rządowej za lata 2012-2016

\begin{tabular}{lllllll}
\hline Lp. & Nazwa działu & 2012 & 2013 & 2014 & 2015 & 2016 \\
\hline 1. & Zdrowie & $\mathrm{A}$ & $\mathrm{A}$ & $\mathrm{A}$ & $\mathrm{B}$ & $\mathrm{A}$ \\
2. & Rolnictwo, Rozwój Wsi i Rynki Rolne i Rybołówstwo* & $\mathrm{A}$ & $\mathrm{A}$ & $\mathrm{A}$ & $\mathrm{A}$ & $\mathrm{A}$ \\
3. & Skarb Państwa & $\mathrm{A}$ & $\mathrm{A}$ & $\mathrm{A}$ & $\mathrm{A}$ & $\mathrm{A}$ \\
4. & Sprawy Wewnętrzne & $\mathrm{B}$ & $\mathrm{B}$ & $\mathrm{A}$ & $\mathrm{B}$ & $\mathrm{B}$ \\
5. & Nauka i Szkolnictwo Wyższe & $\mathrm{A}$ & $\mathrm{A}$ & $\mathrm{A}$ & $\mathrm{B}$ & $\mathrm{B}$ \\
\hline
\end{tabular}

* W 2016 roku bez działu Rybołówstwo.

Źródło: badania własne na podstawie sprawozdań z realizacji zadań komitetów audytu w latach 2012-2016.

Jak wynika z tabeli 3, większość komitetów audytu przyjęła, że nie ma potrzeby sygnalizowania istotnych rodzajów ryzyka lub słabości kontroli zarządczej, oraz że działania wykonywane w ramach kontroli zarządczej są dostosowane do aktualnych potrzeb i zapewniają zgodność wykonywanych czynności z procedurami i przepisami oraz umożliwiają bieżące reagowanie na nieprawidłowości i monitorowanie efektywności wdrożonych mechanizmów kontrolnych ${ }^{2}$. Porównując dane z tabel 2 i 3, należy ostrożnie założyć, że więcej pozytywnych ocen funkcjonowania kontroli zarządczej przyjęły komitety audytu niż ministrowie. Na podstawie analizy sprawozdań z realizacji zadań komitetów audytu za lata 2012-2016 można również wskazać przypadki, w których rekomendowana przez komitet audytu ocena funkcjonowania kontroli zarządczej była wyższa od rzeczywistej oceny wyrażonej przez ministra w oświadczeniu za dany rok, co może wskazywać na wagę pozaaudytowych źródeł informacji przy ocenie kontroli zarządczej.

\section{Uwagi końcowe}

Podsumowując, należy podkreślić, że działania komitetu audytu nie tylko sprowadzają się do świadczenia doradztwa na rzecz ministra kierującego działem w zakresie zapewnienia funkcjonowania adekwatnej, skutecznej i efektywnej kontroli zarządczej, sygnalizując

\footnotetext{
${ }^{2}$ Komitet audytu dla działów administracji rządowej - nauka i szkolnictwo wyższe w Ministerstwie Nauki i Szkolnictwa Wyższego, rekomendował (od 2012 r.) nie wydawanie szczegółowych wytycznych z zakresie kontroli zarządczej (mimo stwierdzenia zastrzeżeń) z uwagi na to, że większość jednostek w dziale to uczelnie autonomiczne.
} 
ogólne słabości i rodzaje ryzyka dotyczące jej funkcjonowania, ale również odnoszą się do konkretnych obszarów oraz formułowania rekomendacji w ich zakresie (Podsumowanie sprawozdań..., 2015, s. 24). Należy również zaznaczyć, że komitet audytu nie jest odpowiedzialny za ostateczny kształt oceny o stanie kontroli zarządczej, a minister nie musi brać pod uwagę zaleceń audytu wewnętrznego przy jej ocenie.

\section{Literatura}

Chojna-Duch, E. (2010). Próba systematyzacji pojęć i zadań z dziedziny kontroli i audytu wewnętrznego na podstawie ustawy o finansach publicznych, Kontrola Państwowa, 330, 47-62.

Dobre praktyki komitetów audytu w sektorze finansów publicznych (2013). Warszawa: Ministerstwo Finansów.

Kontrola zarządcza w sektorze finansów publicznych. Istota, unormowania prawne i otoczenie (2012). Warszawa: Ministerstwo Finansów.

Kotarski, D. (2014). Organizacja kontroli zarządczej w Ministerstwie Zdrowia. Zeszyty Naukowe Uniwersytetu Szczecińskiego, 833. Finanse, Rynki Finansowe, Ubezpieczenia, 72, 77-85.

Mituś, A. (2015). Monitorowanie i ocena systemu kontroli zarządczej. W: M. Ćwiklicki (red.), Podstawowe zagadnienia kontroli zarządczej. Poradnik dla jednostek samorządu terytorialnego (s. 135-162). Kraków: Wydawnictwo MSAP Uniwersytet Ekonomiczny w Krakowie.

Oświadczenie o stanie kontroli zarządczej Ministra Nauki i Szkolnictwa Wyższego za rok: 2012, 2013, 2014,2015 i 2016.

Oświadczenie o stanie kontroli zarządczej Ministra Spraw Wewnętrznych i Administracji za rok: 2012, 2013, 2014, 2015 i 2016.

Oświadczenie o stanie kontroli zarządczej Ministra Rolnictwa i Rozwoju Wsi za rok: 2012, 2013, 2014, 2015 i 2016.

Oświadczenie o stanie kontroli zarządczej Ministra Skarbu Państwa za rok: 2012, 2013, 2014 i 2015.

Oświadczenie o stanie kontroli zarządczej Ministra Zdrowia za rok: 2012, 2013, 2014, 2015 i 2016.

Podsumowanie sprawozdań komitetów audytów z realizacji zadań w 2015 r. (2016). Warszawa: Ministerstwo Finansów.

Rozporządzenie Ministra Finansów z dnia 2 grudnia 2010 r. w sprawie wzoru oświadczenia o stanie kontroli zarządczej (Dz.U. nr 238, poz. 1581).

Rozporządzenie Ministra Finansów z dnia 20 maja 2016 r. zmieniające rozporządzenie w sprawie komitetu audytu (Dz.U. poz. 782).

Sprawozdanie z realizacji zadań komitetu audytu dla działów nauka i szkolnictwo wyższe w 2012, 2013, 2014, 2015 i 2016 roku.

Sprawozdanie z realizacji zadań komitetu audytu dla działów: rolnictwo, rozwój wsi, rynki rolne i rybołówstwo w 2012, 2013, 2014 i 2015 roku.

Sprawozdanie z realizacji zadań komitetu audytu dla działów: rolnictwo, rozwój wsi i rynki rolne 2016 roku.

Sprawozdanie z realizacji zadań komitetu audytu dla działu administracji rządowej - Zdrowie w roku 2012, 2013, 2014, 2015 i 2016.

Sprawozdanie z realizacji zadań komitetu audytu dla działu skarb państwa w 2012, 2013, 2014, 2015 i 2016 roku.

Sprawozdanie z realizacji zadań komitetu audytu dla działu sprawy wewnętrzne w 2012, 2013, 2014, 2015 i 2016 roku.

Ustawa z dnia 27 sierpnia 2009 r. o finansach publicznych, (t.j. Dz.U. 2016, poz. 1870 z późn. zm.).

Winiarska, K., Postuła, M. (2012). Wyznaczanie celów i mierników ich realizacji elementem kontroli zarządczej. W: K. Winiarska (red.), Kontrola zarządcza w jednostkach sektora finansów publicznych (s. 33-45). Warszawa: Wolters Kluwer Polska. 
THE ROLE OF AUDIT COMMITTEE IN EVALUATING MANAGEMENT CONTROL IN A MINISTRY

Abstract: Purpose - The paper shows the role of audit committees in evaluating management control in public administration in Poland. The primary purpose of an audit committee is to provide information on the management control process and the internal audit process for their ministries, ensuring compliance with laws and regulations.

Design/methodology/approach - Based on the current regulations, there were used analysis of documents of audit committee reports and the minister's statements on management control in years 2012-2016.

Findings - Apart from that in the paper one can find an example of functioning of an audit committee and its objectives, tasks and the role in evaluating of management control in a ministry.

Originality/value - The paper shows originality of functioning of audit committee, management control system and internal audit cells in a ministry and description of some problems and improvements in these institutions.

Keywords: audit committee, management control, internal audit, ministry

\section{Cytowanie}

Kotarski, D. (2017). Rola komitetu audytu w ocenie funkcjonowania kontroli zarządczej w ministerstwie. Finanse, Rynki Finansowe, Ubezpieczenia, 3 (87/1), s. 177-186. DOI: 10.18276/frfu.2017.87/1-16. 